\title{
NK/T-cell non-Hodgkin's lymphoma with secondary haemophagocytic lymphohistiocytosis treated with matched unrelated donor allogeneic stem cell transplant
}

\author{
Seongseok Yun, ${ }^{1}$ Josephine A Taverna, ${ }^{2}$ Soham D Puvvada, ${ }^{2}$ Faiz Anwer ${ }^{1}$
}

'Department of Internal Medicine, University of Arizona Medical Center, Tucson, Arizona, USA

${ }^{2}$ Department of Hematology and Oncology, University of Arizona Medical Center, Tucson, Arizona, USA

\section{Correspondence to}

Dr Seongseok Yun,

namaska97@gmail.com

Accepted 25 July 2014
CrossMark

To cite: Yun S, Taverna JA, Puvvada SD, et al. BMJ Case Rep Published online:

[please include Day Month Year] doi:10.1136/bcr-2014205602

\section{DESCRIPTION}

A 39-year-old Hispanic man who was recently diagnosed with stage IV NK/T-cell lymphoma nasal type from paratracheal lymph node and bone marrow biopsy (figures 1 and 2) presented to the emergency department with fever, chills and general weakness for 2 weeks. The patient was tachycardic, tachypneic and hypotensive. Physical examination showed marked hepatosplenomegaly and complete blood count revealed pancytopaenia. Liver function test demonstrated total bilirubin $19.1 \mathrm{mg} / \mathrm{dL}$, asparate aminotransferace $144 \mathrm{IU} / \mathrm{L}$, alamine transaminase $92 \mathrm{IU} / \mathrm{L}$, alkaline phosphatase $595 \mathrm{IU} / \mathrm{L}$ and fibrinogen $54 \mathrm{mg} / \mathrm{dL}$ (figure 3). Iron panel revealed iron $203 \mu \mathrm{g} / \mathrm{dL}$, serum ferritin $48900 \mathrm{ng} / \mathrm{mL}$ and transferrin saturation 94\%.
Subsequent positron emission tomography (PET) and MRI demonstrated marked hepatosplenomegaly and multiple mediastinal and retroperitoneal lymph node enlargement with avid fluorodeoxyglucose update (figure 4), meeting the diagnostic criteria of haemophagocytic lymphohistiocytosis (HLH; table 1). ${ }^{1}$

Infectious work up was all negative except Epstein-Barr virus (EBV) quantitative PCR measure at $1.7 \times 10^{9} \mathrm{IU} / \mathrm{mL}$, for which high-dose valacyclovir was initiated. Induction chemotherapy with an ESHAP, EPOCH regimen ${ }^{2}$ and combination chemotherapy with L-asparaginase, methotrexate, dexamethasone followed by matched unrelated donor allogeneic stem cell transplant were performed for the treatment of HLH and NK/T-cell
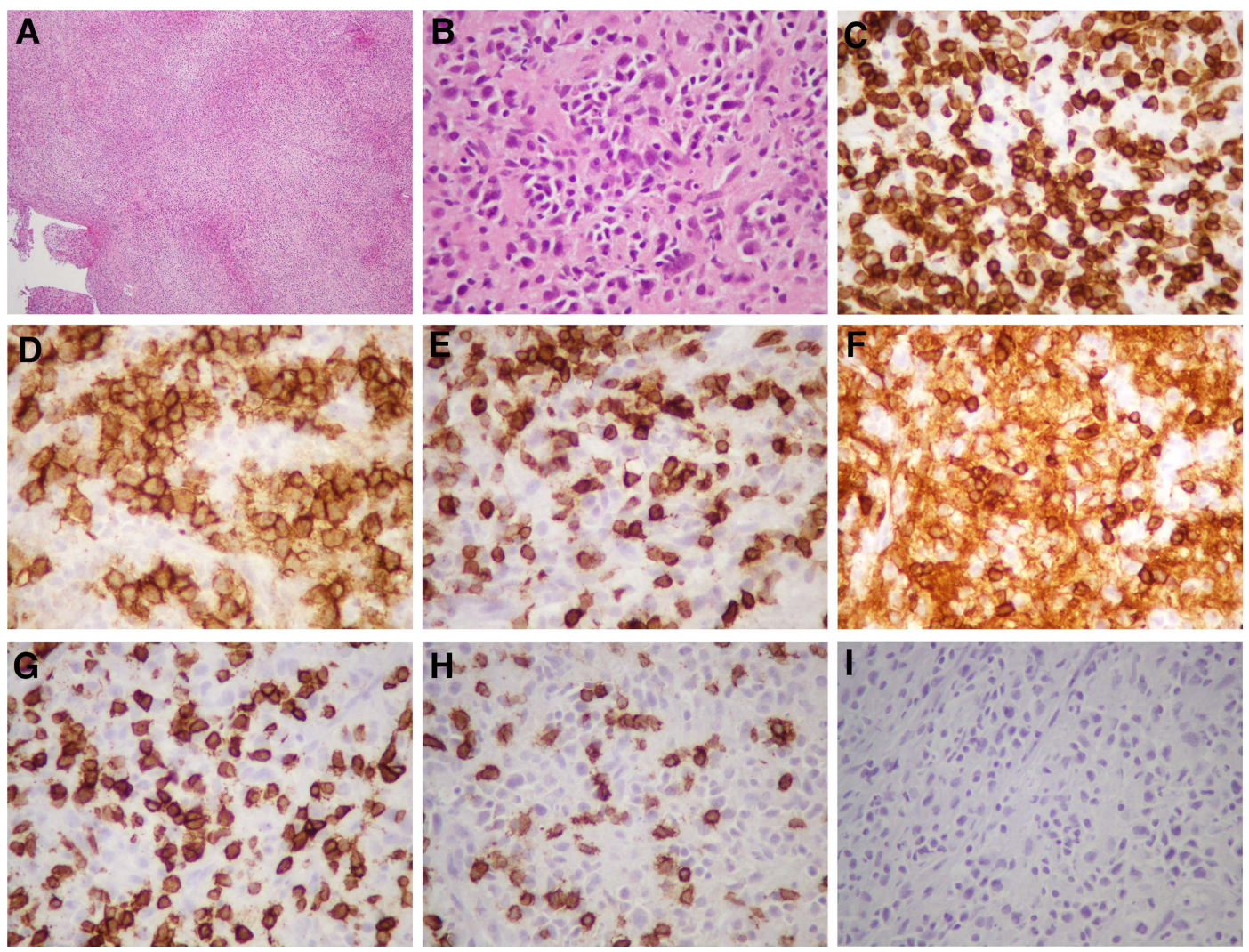

Figure 1 Paratracheal lymph node biopsy showing diffuse infiltration by large atypical cells with coarse chromatin, prominent nucleoli and abundant eosinophilic cytoplasm intermixed with a smaller number of small mature lymphocytes and histiocytes (A and B). Apoptotic bodies and numerous mitotic figures are noted. There is no necrosis, granulomata or vasculitis present. Immunohistochemical stains demonstrated malignant cells positive for CD3 (C), CD56 (D) and EBER-ISH (E), but negative for the rest of the T-cell markers including CD4 (F), CD5 (G) and CD8 (H). The background small lymphocytes are mostly T cells and only a few CD20 B cells are observed (I). 

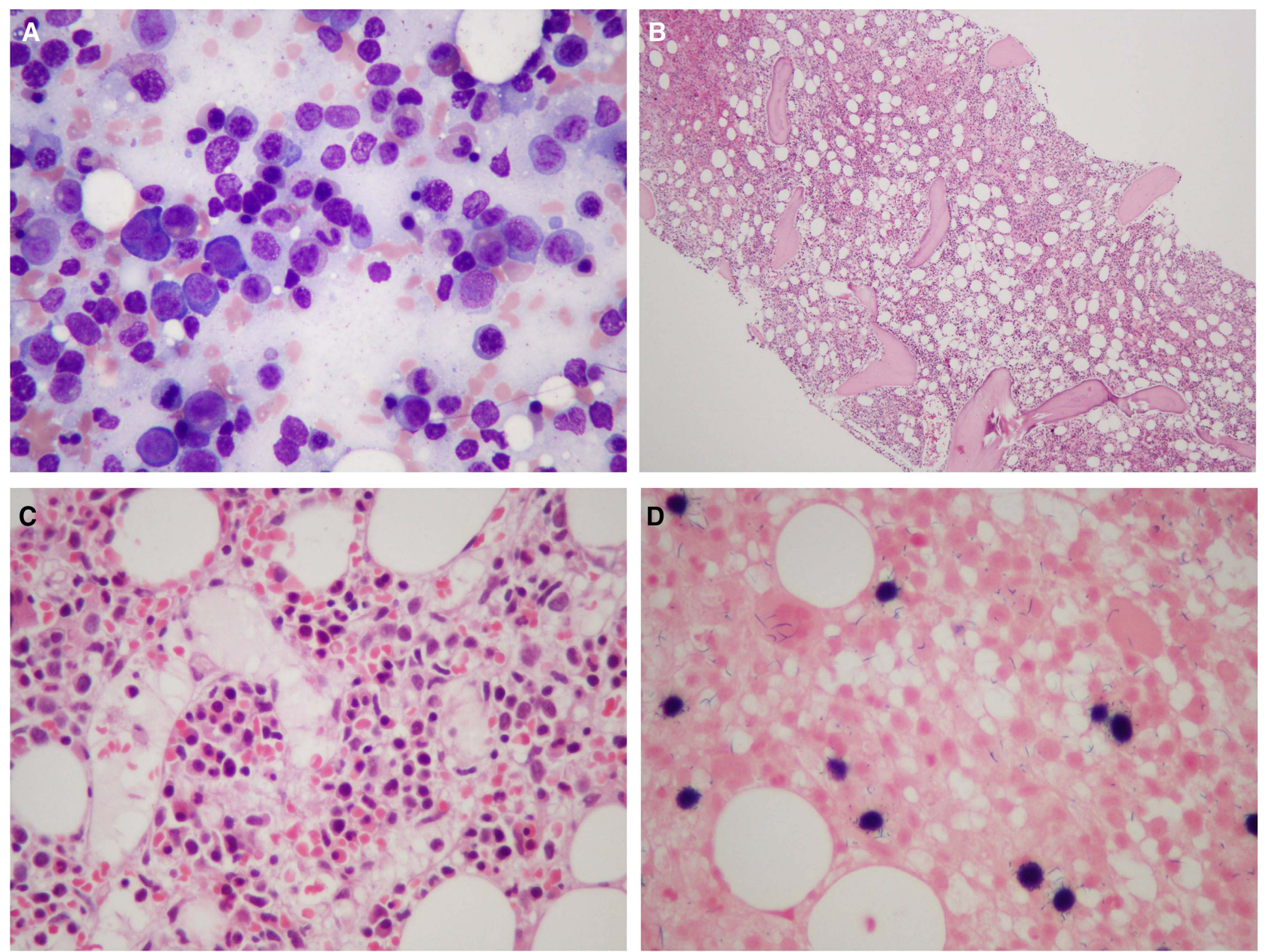

Figure 2 Bone marrow aspirate and core biopsy. Bone marrow aspirate (A) and biopsy (B and C) demonstrated cellularity of $60 \%$, trilineage haematopoiesis with myeloid:erythroid ratio of $1.04,5.4 \%$ of lymphocytes and 1-2\% of CD56 and EBER+large atypical lymphocytes (D) suggesting low level of bone marrow involvement with NK/T-cell lymphoma. No clusters of abnormal cells are observed. Megakaryocytes are normal in their morphology and number. No granulomata or fibrosis is observed.

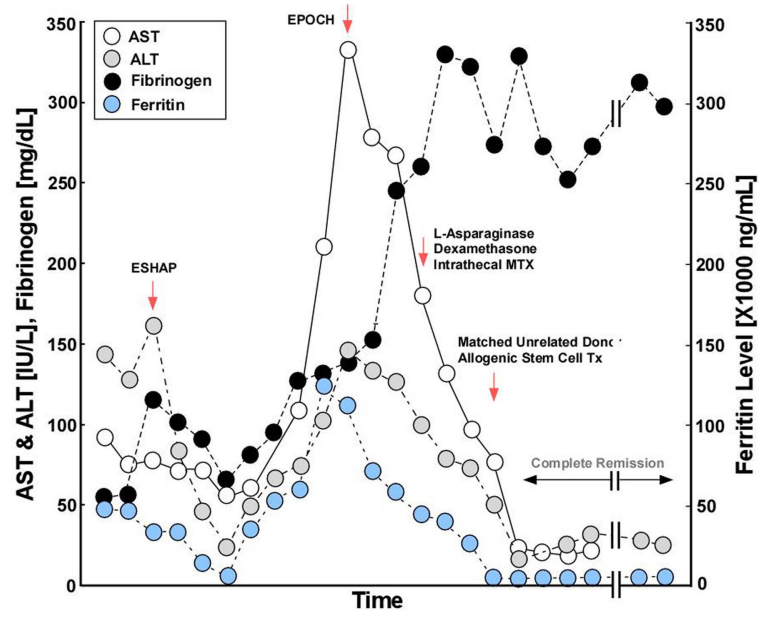

Figure 3 Laboratory values during the hospital course. The patient presented with elevated liver enzymes and ferritin levels, which became normalised on induction chemotherapy with an ESHAP and EPOCH regimen. The patient achieved complete remission with subsequent combination chemotherapy with L-asparaginase, dexamethasone and intrathecal methotrexate followed by matched unrelated donor allogeneic stem cell transplant with normal laboratory values (AST, aspirate aminotransferase; ALT, alamine transaminase; MTX, methotrexate). lymphoma, respectively. ${ }^{3}$ Bilirubin, transaminase and ferritin levels became normalised (figure 3) and EBV PCR became undetectable over the treatment course. Bone marrow biopsy on post-transplant day 72 demonstrated no evidence of haemophagocytes or abnormal NK/T-cell population, specifically CD56/EBER+ atypical lymphoid cells. Subsequent PET scan on post-transplant day 75 confirmed complete remission (figure 5).

HLH is a syndrome with clinical manifestation of fever, splenomegaly, transaminitis and cytopaenia (table 1). It is frequently associated with underlying malignancy, rheumatoid disease, infection, genetic defect of cytotoxicity or reduced NK cell function leading to macrophages activation. ${ }^{4}$ Etoposide including combination regimen as well as intrathecal methotrexate in patients with central nervous system (CNS) involvement are current treatment recommendations. ${ }^{5}$ In the familial, relapsed or progressive HLH, stem cell transplant is an alternative option with $50-60 \%$ of long-term disease-free survival. ${ }^{5}$ NK/T-cell non-Hodgkin's lymphoma (NHL) is one of the most common malignancies associated with secondary HLHs. L-asparaginase including concurrent chemoradiation treatment is the treatment of choice for NK/T-cell NHL and stem cell transplant can be considered in refractory disease or young patients who achieve complete remission. ${ }^{3}$ 

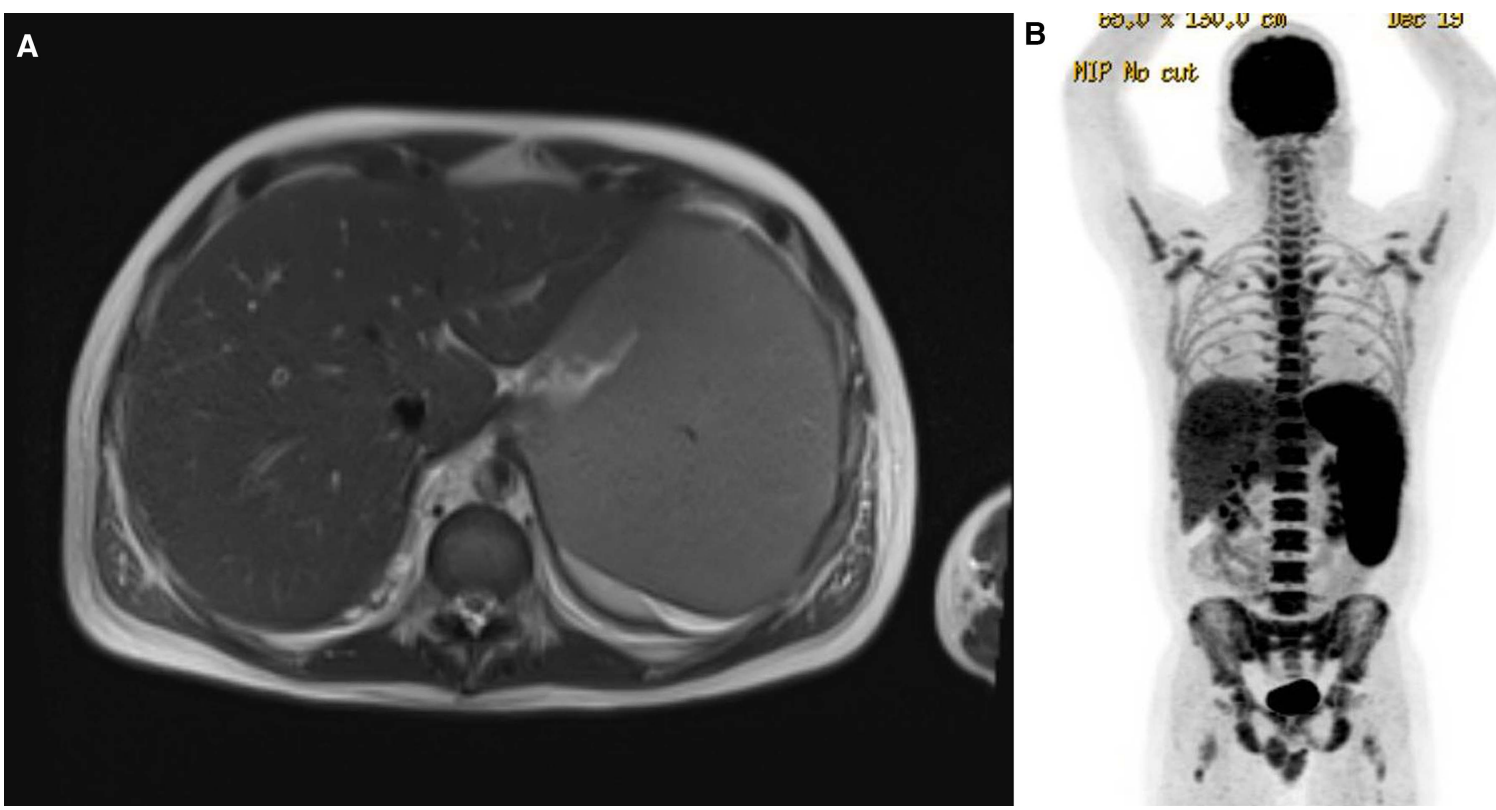

Figure 4 Pretransplant MRI and positron emission tomography (PET) scan. MRI of the abdomen (A) showing marked splenomegaly, multiple retroperitoneal lymph nodes including aortocaval adenopathy and mesenteric mass. Heterogeneous hepatic parenchymal enhancement with periportal oedema is observed. PET scan (B) demonstrated avid fluorodeoxyglucose (FDG) uptake with max standardised uptake values (SUV) 17 in the spleen. Also, hypermetabolic mesenteric and retroperitoneal lymph nodes are observed. Pancreas, adrenal glands and kidneys are unremarkable.

Table 1 Diagnostic criteria of $\mathrm{HLH}^{1}$

\begin{tabular}{|c|c|}
\hline Molecular diagnosis of FHLH & Clinical diagnosis of HLH \\
\hline $\begin{array}{l}\text { Mutation ins } \\
\text { 1. BIRC4 (Baculoviral IAP repeat containing } \\
\text { protein 4) or XIAP (X linked inhibitor of } \\
\text { apoptosis protein) } \\
\text { 2. PRF1 (Perforin-1/Pore forming protein-1) } \\
\text { 3. Rab27a (Ras-related protein Rab-27a) } \\
\text { 4. SH2D1A (SH2 domain-containing protein } \\
\text { 1A) } \\
\text { 5. STX11 (Syntaxin 11) } \\
\text { 6. STXBP2 (Syntaxin-binding protein 2) } \\
\text { 7. UNC13D (Protein unc-13 homolog D) }\end{array}$ & $\begin{array}{l}\text { Five of the eight criteria fulfilled } \\
\text { 1. Fever } \geq 38.5^{\circ} \mathrm{C} \\
\text { 2. Splenomegaly } \\
\text { 3. Cytopaenia of at least two } \\
\text { lineage } \\
\text { 4. Haemophagocytosis in the } \\
\text { tissue } \\
\text { 5. Triglyceride }>265 \mathrm{mg} / \mathrm{dL} \text { or } \\
\text { fibrinogen }<150 \mathrm{mg} / \mathrm{dL} \\
\text { 6. Ferritin }>500 \mathrm{ng} / \mathrm{mL} \\
\text { 7. Elevated CD25 } \\
\text { 8. Low or absent NK cell activity }\end{array}$ \\
\hline
\end{tabular}

FHLH, familial haemophagocytic lymphohistiocytosis; HLH, haemophagocytic lymphohistiocytosis.

\section{Learning points}

- Macrophage activation plays a pivotal role in haemophagocytic lymphohistiocytosis (HLH) syndrome and thorough investigation for the underlying pathology including malignancy, rheumatoid disease, infection and genetic disorder are important.

- Pathological confirmation of haemophagocytosis in tissues is only one of the eight current clinical criteria for the diagnosis of $\mathrm{HLH}$. Its demonstration is not mandatory if sufficient numbers of other criteria are met.

- NK/T-cell non-Hodgkin's lymphoma is the most common underlying malignancy associated with secondary $\mathrm{HLH}$. L-asparaginase including combination chemotherapy is the current recommendation and allogeneic stem cell transplant can be considered in patients with refractory disease or young patients who achieve complete remission.

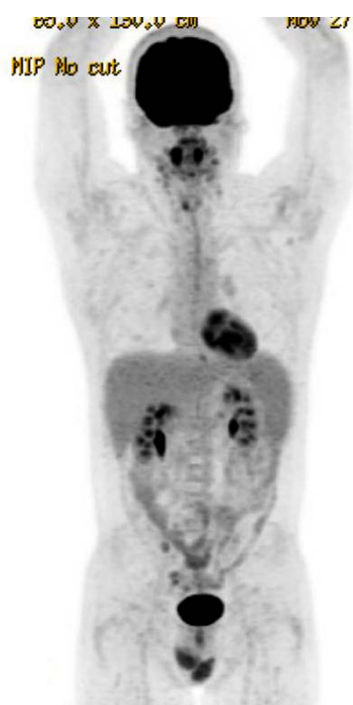

Figure 5 Post-transplant positron emission tomography scan showing no evidence of lymphoadenopathy. Liver, spleen, pancreas, adrenal glands and kidneys are unremarkable and there is no fluorodeoxyglucose avid osseous disease.

Acknowledgements Histology figures were taken by Dr Carlos L Cantu and the authors thank him for his contribution.

Contributors All authors were involved in the care of the patient, collecting data and writing up the case report. SY reviewed the literature and revised the manuscript.

Competing interests None.

Patient consent Obtained.

Provenance and peer review Not commissioned; externally peer reviewed.

\section{REFERENCES}

1 Henter Jl, Horne A, Aricó M, et al. HLH-2004: diagnostic and therapeutic guidelines for hemophagocytic lymphohistiocytosis. Pediatr Blood Cancer 2007;48:124-31.

2 Jordan $\mathrm{MB}$, Allen $\mathrm{CE}$, Weitzman $\mathrm{S}$, et al. How I treat hemophagocytic lymphohistiocytosis. Blood 2011;118:4041-52. 
3 Tse E, Kwong YL. How I treat NK/T-cell lymphomas. Blood 2013;121:4997-5005.

4 Fisman DN. Hemophagocytic syndromes and infection. Emerg Infect Dis 2000;6:601-8.
5 Trottestam $\mathrm{H}$, Horne A, Aricò M, et al. Chemoimmunotherapy for hemophagocytic lymphohistiocytosis: long-term results of the HLH-94 treatment protocol. Blood 2011:118:4577-84.

Copyright 2014 BMJ Publishing Group. All rights reserved. For permission to reuse any of this content visit http://group.bmj.com/group/rights-licensing/permissions.

BMJ Case Report Fellows may re-use this article for personal use and teaching without any further permission.

Become a Fellow of BMJ Case Reports today and you can:

- Submit as many cases as you like

- Enjoy fast sympathetic peer review and rapid publication of accepted articles

- Access all the published articles

- Re-use any of the published material for personal use and teaching without further permission

For information on Institutional Fellowships contact consortiasales@bmjgroup.com

Visit casereports.bmj.com for more articles like this and to become a Fellow 